\title{
Actinobacillus minor sp. nov., Actinobacillus porcinus sp. nov., and Actinobacillus indolicus sp. nov., Three New V Factor-Dependent Species from the Respiratory Tract of Pigs
}

\author{
K. MøLLER, ${ }^{1 *}$ V. FUSSING, ${ }^{1}$ P. A. D. GRIMONT, ${ }^{2}$ B. J. PASTER, ${ }^{3}$ \\ F. E. DEWHIRST, ${ }^{3}$ AND M. KILIAN ${ }^{4}$
}

\begin{abstract}
Department of Microbiology, Danish Veterinary Laboratory, DK-1790 Copenhagen $V^{1}$ and Department of Medical Microbiology and Immunology, University of Aarhus, DK-8000 Aarhus $C{ }^{4}$ Denmark; Unite des Enterobacteries, INSERM Unit 389, Institut Pasteur, 75724 Paris Cedex 15, France ${ }^{2}$; and Department of

Molecular Genetics, Forsyth Dental Center, Boston, Massachusetts 02115 3
\end{abstract}

\begin{abstract}
The results of DNA-DNA relatedness experiments and comparisons of sequences of genes coding for $16 \mathrm{~S}$ rRNA were used to determine the genetic relationships of selected $V$ factor-dependent species belonging to the family Pasteurellaceae and obtained from the porcine respiratory tract. These results showed that the Minor group and taxa $C, D$ plus $E$, and $F$ are distinct phylogenetic groups that are separate from each other and from other members of the family Pasteurellaceae. On the basis of these results, three new species, corresponding to the Minor group, taxa D plus E, and taxon F, are proposed; the names of these new species are Actinobacillus minor (type strain, NM305), Actinobacillus porcinus (type strain, NM319), and Actinobacillus indolicus (type strain, 46KC2), respectively.
\end{abstract}

On the basis of extensive phenotypic characteristics, we identified $\mathrm{V}$ factor-dependent species belonging to the family Pasteurellaceae present in the porcine upper respiratory tract $(14,15)$. We found that in addition to Actinobacillus pleuropneumoniae, the causative agent of porcine pleuropneumonia, Haemophilus parasuis, the causative agent of Glässer's disease, and the Minor group (13), three other distinct taxa, previously designated taxa $\mathrm{D}, \mathrm{E}$, and $\mathrm{F}$, colonize the porcine respiratory tract (15). Recent DNA-DNA hybridization studies of members of the family Pasteurellaceae revealed that the requirement for $\mathrm{V}$ factor is not an exclusive feature of the genus Haemophilus, but may be a feature of members of all three genera of this family $(17,18,20)$. Comparative analysis of sequences of genes coding for 16S rRNA (16S rDNA) has been useful for differentiating species in the family Pasteurellaceae $(6,7)$. While several strains of $A$. pleuropneumoniae and $H$. parasuis and a few strains belonging to the Minor group have been analyzed by DNA-DNA hybridization $(1,16)$, no strains belonging to taxa $D, E$, and $F$ have been included in such studies. Likewise, 16S rDNA sequence analysis has never been performed with isolates belonging to taxa D, E, and F. The purpose of this study was to use DNA-DNA relatedness and $16 \mathrm{~S}$ rDNA sequence comparisons to determine the intra- and intergenetic relationships of the Minor group and taxa C, D, E, and $\mathrm{F}$ with selected $\mathrm{V}$ factor-dependent and $\mathrm{V}$ factor-independent members of the family Pasteurellaceae.

\section{MATERIALS AND METHODS}

Bacterial strains. A total of 28 strains were included in this study. Table 1 shows the sources of $22 \mathrm{~V}$-factor dependent porcine strains belonging to the Pasteurellaceae, the type strains of the type species of the genera Actinobacillus, Pasteurella, and Haemophilus (Actinobacillus lignieresii, Pasteurella multocida, and Haemophilus influenzae), and the type strains of species commonly isolated from pigs ( $A$. pleuropneumoniae, Actinobacillus suis, and $H$. parasuis). Two taxon $\mathrm{C}$ strains described by Kilian (12) were included because of their V factor dependence and their presumed porcine origin.

All of the strains were stored as lyophilized cultures. Phenotypic characteristics of the 22 porcine strains have been described elsewhere (15). The bacteria used for DNA preparation were propagated in 2.5 -liter portions of brain heart infu-

* Corresponding author. sion broth (Difco Laboratories, Detroit, Mich.) supplemented with $10 \mathrm{mg}$ of NAD per liter. Each inoculated broth preparation was incubated for $48 \mathrm{~h}$ in air at $37^{\circ} \mathrm{C}$. The two strains belonging to taxon $\mathrm{E}$ failed to grow in brain heart infusion broth and consequently were grown on chocolate agar plates; for each of these strains 40 plates were incubated for $48 \mathrm{~h}$ at $37^{\circ} \mathrm{C}$.

Preparation of DNA for DNA-DNA hybridization. The bacteria were harvested by centrifugation at $8,000 \times g$ for $10 \mathrm{~min}$. The pellet from each 2.5 -liter culture was suspended in $120 \mathrm{ml}$ of distilled water containing $0.05 \mathrm{M}$ Tris, $0.05 \mathrm{M}$ EDTA, and $0.1 \mathrm{M} \mathrm{NaCl}(\mathrm{pH} 8.0)$. The bacteria harvested from each group of 40 chocolate agar plates were suspended in $120 \mathrm{ml}$ of the same solution. The cells were lysed in $2.6 \mathrm{ml}$ of a $25 \%$ (wt/vol) aqueous solution of sodium dodecyl sulfate (Sigma Chemical Co., St. Louis, Mo.) and $0.4 \mathrm{ml}$ of a $2 \%$ (wt/vol) pronase (Calbiochem-Behring, La Jolla, Calif.) solution. Each mixture was vigorously shaken and incubated at $37^{\circ} \mathrm{C}$ overnight. DNA was extracted and purified from the cell lysate by a previously described procedure (3). The DNAs in the solutions were sheared by sonication, dialyzed overnight against $0.042 \mathrm{M} \mathrm{NaCl}$, and stored at $4^{\circ} \mathrm{C}$ over a layer of chloroform.

DNA-DNA hybridization. Native DNA was labeled in vitro by nick translation (3). The S1 nuclease-trichloroacetic acid procedure was used for hybridization (9). Labeled DNA (about $10 \mathrm{ng}$ ) and unlabeled DNA (75 $\mu \mathrm{g}$ ) were heat denatured, the $\mathrm{NaCl}$ concentration of the preparation (final volume, $0.5 \mathrm{ml}$ ) was adjusted to $0.42 \mathrm{M}$, and the preparation was incubated at $60^{\circ} \mathrm{C}$ for $16 \mathrm{~h}$.

The $T_{m}$ (the temperature at which $50 \%$ of the reassociated DNA became hydrolyzable by $\mathrm{S} 1$ enzyme treatment) was determined for some of the isolates. The $\Delta T_{m}$ (the difference between the $T_{m}$ of a homologous reaction and the $T_{m}$ of a heterologous reaction) was used to estimate the level of divergence between two organisms (2).

16S rDNA sequencing. Chromosomal DNA was extracted as described by Christensen et al. (5). The 16S rDNA was amplified by PCR and sequenced by the cycle sequencing method (10). Programs for data entry, editing, sequence alignment, secondary-structure comparison, similarity matrix generation, and phylogenetic tree construction were written in Microsoft QuickBASIC for use on IBM PC-AT and compatible computers (6). Similarity matrices were constructed from aligned sequences by using only those sequence positions for which $90 \%$ of strains had data. Similarity matrices were corrected for multiple base changes by the method of Jukes and Cantor (11). The neighbor-joining method of Saitou and Nei (21) was used for phylogenetic tree construction.

Determination of $\mathbf{G}+\mathbf{C}$ content of the DNA. The $\mathrm{G}+\mathrm{C}$ contents of three DNA samples were determined by O. Bouvet (Institut Pasteur, Paris, France). DNA was hydrolyzed with P1 nuclease (8). The nucleotides produced were separated by high-performance liquid chromatography as described by Perrone and Brown (19). The $\mathrm{G}+\mathrm{C}$ content was determined from the nucleotide ratios by using hydrolyzed bacteriophage lambda DNA as the standard.

Nucleotide sequence accession numbers. The nucleotide sequences of the three bacterial strains examined in this study are available for electronic retrieval from the EMBL, GenBank, and DDBJ databases under the following accession numbers: strain $\mathrm{NM} 35^{\mathrm{T}}\left(\mathrm{T}=\right.$ type strain), U65582; strain $\mathrm{NM} 319^{\mathrm{T}}$, U65583; and strain $46 \mathrm{KC} 2,{ }^{\mathrm{T}} \mathrm{U} 65584$. 
TABLE 1. Reference and field strains examined

\begin{tabular}{lll}
\hline \multicolumn{1}{c}{ Taxon } & \multicolumn{1}{c}{ Strain(s) } & Source or reference $^{a}$ \\
\hline Minor group & $565,566,52 \mathrm{T3a}$ & 13 \\
& $202(=\mathrm{HK} 683)$ & Biberstein \\
& $\mathrm{NM} 305^{\mathrm{T}}, 562$ & Rosendal \\
& 559,273 & Musser \\
Taxon D & $596,27 \mathrm{Kb3}$ & 13 \\
& $\mathrm{NM} 319^{\mathrm{T}}, \mathrm{K} 13$ & Rosendal \\
& $\mathrm{K} 12$ & \\
Taxon E & $20 \mathrm{~b}$ & 13 \\
& $30 \mathrm{sp}$ & Nielsen \\
Taxon F & $\mathrm{K} 1, \mathrm{~K} 4,46 \mathrm{KC} 2^{\mathrm{T}}$ & 13 \\
& F6, F7 & Heidt \\
Taxon C & 5015,5111 & CAPM \\
A. pleuropneumoniae & ATCC $27088^{\mathrm{T}}$ & ATCC \\
A. lignieresii & NCTC $4189^{\mathrm{T}}$ & NCTC \\
A. suis & ATCC $15557^{\mathrm{T}}$ & ATCC \\
P. multocida & NCTC $10322^{\mathrm{T}}$ & NCTC \\
H. influenzae & ATCC $33391^{\mathrm{T}}$ & ATCC \\
H. parasuis & ATCC $19417^{\mathrm{T}}$ & ATCC \\
\hline
\end{tabular}

${ }^{a}$ Biberstein, E. L. Biberstein, University of California, Davis; Rosendal, S. Rosendal, University of Guelph, Guelph, Ontario, Canada; Musser, J. Musser, University of Pennsylvania, Philadelphia; Nielsen, R. Nielsen, Danish Veterinary Laboratory, Copenhagen, Denmark; Heidt, M. Heidt, Justus Liebig-Universität, Giessen, Germany; CAPM, Collection of Animal Pathogenic Microorganisms, Brno-Type Medlánky, Czechoslovakia; ATCC, American Type Culture Collection, Rockville, Md.; NCTC, National Collection of Type Cultures, Colindale, London, United Kingdom.

\section{RESULTS}

DNA-DNA hybridization. The DNA-DNA relatedness data are shown in Table 2. Low levels of DNA relatedness were detected between representative strains of the five taxa examined in this study (the Minor group and taxa C, D, E, and F) and the type strains of the type species of the genera Actinobacillus, Pasteurella, and Haemophilus. Each of the five taxa exhibited only 6 to $33 \%$ DNA relatedness with $A$. lignieresii, 4 to $15 \%$ DNA relatedness with $P$. multocida, and 3 to $14 \%$ DNA relatedness with $H$. influenzae. Low levels of DNA relatedness were also detected between the five taxa and the type strains of 4. pleuropneumoniae (levels of relatedness, 5 to 20\%), A. suis (3 to $23 \%$ ), and $H$. parasuis (6 to $39 \%$ ).

Six of the eight strains in the Minor group formed a homogeneous group (DNA group I) (Table 2). When labeled DNA from one of the six strains (strain $\mathrm{NM} 305^{\mathrm{T}}$ ) was used, these strains were 80 to $98 \%$ related, with $\Delta T_{m}$ values of $2.3^{\circ} \mathrm{C}$ or less. The remaining two strains (strains 202 and 565) were only distantly related to each other (levels of DNA relatedness, 39 to $49 \%$ ) and were related to the DNA group I strains to varying degrees. Thus, strain 202 exhibited 58 to $77 \%$ DNA relatedness to the DNA group I strains $\left(\Delta T_{m}\right.$ values, $\left.\geq 5.6^{\circ} \mathrm{C}\right)$, and strain 565 exhibited 38 to $48 \%$ DNA relatedness to the DNA group I strains. The DNA group I strains, as well as strains 202 and 565 , exhibited little or no DNA relatedness (levels of similarity, 1 to $26 \%$ ) to members of taxa C, D, E, and F.

The two taxon $\mathrm{C}$ strains formed a homogeneous group and exhibited only 4 to $19 \%$ relatedness to members of the Minor group and taxa D, E, and F.

The two taxon E strains (strains 20b and 30sp) clustered together with three taxon D strains (DNA group II) (Table 2). The DNAs of these strains were 71 to $100 \%$ related, with $\Delta T_{m}$ values of less than $3.6^{\circ} \mathrm{C}$. Two other taxon D strains (DNA group III) (Table 2), which were $84 \%$ related to each other with a $\Delta T_{m}$ of $3.9^{\circ} \mathrm{C}$, exhibited 47 to $59 \%$ DNA relatedness to DNA group II strains. Taxon D and E strains exhibited little or no DNA relatedness (levels of DNA relatedness, 1 to $23 \%$ ) to members of the Minor group and taxa $\mathrm{C}$ and $\mathrm{F}$.

Four taxon $\mathrm{F}$ strains were 66 to $72 \%$ related to each other, with $\Delta T_{m}$ values of $4.0^{\circ} \mathrm{C}$ (DNA group IV) (Table 2). However, strain F7 was more distantly related to this group (levels of DNA relatedness, 38 to $50 \%$ ). DNA group IV strains and strain F7 exhibited little or no DNA relatedness (levels of DNA relatedness, 5 to $26 \%$ ) to members of the Minor group and taxa C, D, and $\mathrm{E}$.

$16 S$ rDNA sequencing. On the basis of the DNA-DNA hybridization results (Table 2), the following three strains were selected for further investigation by $16 \mathrm{~S}$ rDNA sequencing: strains NM305 ${ }^{\mathrm{T}}$ (Minor group, DNA group I), NM319 ${ }^{\mathrm{T}}$ (taxa $\mathrm{D}$ and $\mathrm{E}, \mathrm{DNA}$ group II), and $46 \mathrm{KC}^{\mathrm{T}}$ (taxon $\mathrm{F}$, DNA group IV). The sequence of approximately $95 \%$ of the gene encoding 16S rRNA was determined for each of these strains. Table 3 is a similarity matrix based on the $16 \mathrm{~S}$ rDNA sequences of these strains, other $\mathrm{V}$ factor-dependent species, and representatives of five of the seven phylogenetic groups in the family Pasteurellaceae as described by Dewhirst et al. (7). The 16S rDNA sequences differed from each other at 54 to 73 base positions. A dendrogram was constructed from the similarity matrix (Fig. $1)$. The tree generated was in agreement with previously published phylogenetic trees consisting of seven groups $(6,7)$. Strain $\mathrm{NM} 35^{\mathrm{T}}$ fell into group $4 \mathrm{~B}$, which consisted of Bisgaard taxa 8 and 9, Haemophilus Minor group strain 202, Haemophilus paraphrohaemolyticus, Haemophilus ducreyi, Pasteurella bettyae, Pasteurella haemolyticus, and Bisgaard taxon 5 (7). The closest relative of strain $\mathrm{NM} 305^{\mathrm{T}}$ was Minor group strain 202 (level of sequence similarity, 97.8\%). Strains NM319 ${ }^{\mathrm{T}}$ and $46 \mathrm{KC} 2^{\mathrm{T}}$ both fell into group $3 \mathrm{C}$, which consisted of Haemophilus haemoglobinophilus, Bisgaard taxon 7, Haemophilus paracuniculus, Actinobacillus capsulatus, Pasteurella trehalosii, and two $H$. parasuis strains (6). The closest relatives of strain $46 \mathrm{KC} 2^{\mathrm{T}}$ were the two strains of $H$. parasuis (levels of sequence similarity, 97.4 to $97.7 \%$ ). The closest relatives of strain NM319 ${ }^{\mathrm{T}}$ were one group consisting of strain $46 \mathrm{KC} 2^{\mathrm{T}}$ and the two $H$. parasuis strains and another group consisting of strain NM305 $5^{\mathrm{T}}$ and Minor group strain 202 (levels of sequence similarity, 95.5 to $96.6 \%$ ).

G+C contents of DNAs. DNAs extracted from strains $\mathrm{NM} 305^{\mathrm{T}}, \mathrm{NM} 319^{\mathrm{T}}$, and $46 \mathrm{KC} 2^{\mathrm{T}}$ had $\mathrm{G}+\mathrm{C}$ contents of 38.2 , 41.4 , and $35.5 \mathrm{~mol} \%$, respectively.

Biochemical characteristics. Table 4 shows the differential characteristics of the V factor-dependent porcine species; the data for these characteristics were obtained from reference 15 .

\section{DISCUSSION}

On the basis of DNA-DNA hybridization and 16S rDNA sequencing results, the Minor group and taxa C, D plus E, and $F$ clearly represent new species belonging to the family Pasteurellaceae. The results of the DNA-DNA hybridization experiments revealed that, with one exception, the five taxa previously delineated by biochemical characteristics (15) were only distantly related to each other. The single exception was the three taxon D strains and two taxon E strains which belonged to a single DNA relatedness group (DNA group II). The taxon E strains can be distinguished phenotypically from the taxon $\mathrm{D}$ strains by their negative or weak reactions in most biochemical tests and by their poor growth both on solid media and in liquid media (15). The high levels of DNA relatedness between the taxon $\mathrm{E}$ strains and some taxon D strains supported our previous assumption that taxon $\mathrm{E}$ strains are nearly identical to taxon D strains (15). Our results corroborate those of several previous studies. Borr et al. (1) found that the levels 
TABLE 2. Levels of DNA relatedness among porcine members of the Pasteurellaceae and the type species of the genera Haemophilus, Actinobacillus, and Pasteurella

\begin{tabular}{|c|c|c|c|c|c|c|c|c|c|c|c|c|c|c|}
\hline \multirow{2}{*}{ Taxon } & \multirow{2}{*}{$\begin{array}{c}\text { Homology } \\
\text { group }\end{array}$} & \multirow{2}{*}{$\begin{array}{c}\text { Source of } \\
\text { unlabeled DNA }\end{array}$} & \multicolumn{12}{|c|}{$\%$ Relative binding at $60^{\circ} \mathrm{C}$ with labeled DNA from strain: } \\
\hline & & & 202 & 565 & $\mathrm{NM} 305^{\mathrm{T}}$ & 5015 & $\mathrm{NM} 319^{\mathrm{T}}$ & 30 sp & $20 \mathrm{~b}$ & $27 \mathrm{~Kb} 3$ & K13 & $46 \mathrm{KC} 2^{\mathrm{T}}$ & K1 & F7 \\
\hline \multirow[t]{8}{*}{ Minor group } & & 202 & 100 & 39 & $66(6.1)^{a}$ & 9 & 12 & & & 12 & & 19 & & \\
\hline & & 565 & 49 & 100 & 38 & 7 & 8 & & & 9 & & 14 & & 19 \\
\hline & I & $52 \mathrm{Ta}$ & $69(6.6)$ & 48 & $98(2.3)$ & 9 & 13 & & & 16 & & 22 & & \\
\hline & I & 273 & $77(5.6)$ & 41 & 93 & 4 & 16 & & & 22 & & 26 & & \\
\hline & I & 559 & 63 & 40 & 85 & 4 & 8 & & & 10 & & 16 & & \\
\hline & I & $\mathrm{NM} 305^{\mathrm{T}}$ & 60 & 48 & 100 & 7 & 16 & & & 9 & & 19 & & 20 \\
\hline & I & 562 & 62 & 38 & $86(0.5)$ & 6 & 10 & & & 8 & & 20 & & \\
\hline & I & 566 & 58 & 42 & $80(0.1)$ & 9 & 13 & & & 12 & & 16 & & \\
\hline \multirow[t]{2}{*}{ Taxon C } & & 5015 & 7 & & & 100 & 9 & & & 11 & & 10 & 6 & 7 \\
\hline & & 5111 & 5 & & & 111 & 7 & & & 13 & & 9 & & \\
\hline \multirow[t]{7}{*}{ TaxaDandE } & II & NM319 & 12 & & & 12 & 100 & $90(3.6)$ & 91 & $49(7.8)$ & 59 & 15 & 13 & 10 \\
\hline & II & $30 \mathrm{sp}$ & 1 & & & 12 & & 100 & 79 & 39 & 52 & 8 & & \\
\hline & II & $20 \mathrm{~b}$ & 4 & & & 14 & & & 100 & 54 & & 10 & & \\
\hline & II & K12 & 14 & & & 10 & $71(0.8)$ & 82 & & & 52 & 13 & & \\
\hline & II & 596 & 17 & & & 8 & $76(0.8)$ & 108 & & & 48 & 8 & & \\
\hline & III & $27 \mathrm{~Kb} 3$ & 13 & & & 19 & 50 & & & 100 & $84(3.9)$ & 11 & 23 & 11 \\
\hline & III & K13 & 11 & & & 17 & 47 & & & & 100 & 5 & 17 & 10 \\
\hline \multirow[t]{11}{*}{ Taxon $\mathrm{F}$} & & F7 & 20 & & & 6 & 8 & & & 14 & & 41 & 50 & 100 \\
\hline & IV & $46 \mathrm{KC} 2^{\mathrm{T}}$ & 14 & & & 13 & 11 & & 11 & 10 & & 100 & & 41 \\
\hline & IV & F6 & 16 & & & 18 & 11 & & 18 & 12 & & $64(4.0)$ & 70 & 39 \\
\hline & IV & $\mathrm{K} 1$ & 23 & 5 & 8 & 10 & 6 & & & 6 & & 66 & 100 & 38 \\
\hline & IV & $\mathrm{K} 4$ & 18 & & & 7 & 15 & & & 13 & & 67 & $72(4.0)$ & 42 \\
\hline & & A. pleuropneumoniae & 15 & 11 & 7 & 8 & 5 & & 11 & 8 & & 16 & 20 & 20 \\
\hline & & A. lignieresii & 16 & 16 & 33 & 9 & 6 & & 7 & 11 & & 13 & 19 & 15 \\
\hline & & A. suis & 18 & 18 & 3 & 11 & 6 & & 6 & 7 & & 18 & 23 & 16 \\
\hline & & P. multocida & 7 & 6 & 10 & 15 & 4 & & 9 & 7 & & 13 & 6 & 8 \\
\hline & & H. influenzae & 8 & 3 & 9 & 12 & 7 & & 12 & 8 & & 9 & 14 & 8 \\
\hline & & H. parasuis & 13 & & 20 & 10 & 6 & & 20 & 8 & & 39 & & 30 \\
\hline
\end{tabular}

${ }^{a}$ The values in parentheses are $\Delta T_{m}$ values (in degrees Celsius).

of DNA relatedness between the Minor group and $A$. pleuropneumoniae and $H$. parasuis were less than $20 \%$, and Morozumi et al. (16) reported that taxon $\mathrm{C}$ strains exhibited less than $13 \%$ DNA relatedness to $H$. parasuis and less than $10 \%$ DNA relatedness to $A$. pleuropneumoniae. Furthermore, Dewhirst et al. $(6,7)$ reported that the Minor group (strain 202) and taxon $\mathrm{C}$ could be clearly differentiated from other species of the family Pasteurellaceae on the basis of 16S rDNA sequence data.

According to recently published recommendations of the Ad Hoc Committee on Reconciliation of Approaches to Bacterial Systematics (23), a species includes strains that exhibit approximately $70 \%$ or greater DNA-DNA relatedness and $\Delta T_{m}$ values of $5^{\circ} \mathrm{C}$ or less. In addition, phenotypic characteristics should be consistent with conclusions based on this definition, as stated previously by other workers (22). In the present work, intrageneric variations in DNA relatedness and $\Delta T_{m}$ values were observed for the Minor group, taxa D plus E, and taxon F (Table 2). The values obtained for DNA group I and Minor group strain 202 are at the borderline of species level values (levels of DNA relatedness, 58 to $77 \% ; \Delta T_{m}$ values, less than $6.6^{\circ} \mathrm{C}$ ), and the values obtained for DNA group I and strain 565 , for DNA groups II and III (taxa D and E), and for DNA group IV and taxon F strain F7 are less than species level values (levels of DNA relatedness, 38 to $50 \%$ ). However, there were no phenotypic characteristics that delineated these strains, and thus, strains 202 and 565 were provisionally assigned to DNA group I, DNA group III was provisionally assigned to DNA group II, and strain F7 was provisionally assigned to DNA group IV.

Until recently, the genus Haemophilus was differentiated from the rest of the family Pasteurellaceae by its requirement for either one or both of two growth factors, $\mathrm{X}$ factor (hemin) and $V$ factor (NAD or NADP). However, the results of DNA relatedness studies and $16 \mathrm{~S}$ rDNA sequence analyses have challenged this definition of the genus Haemophilus. On the basis of the results of DNA relatedness studies, Haemophilus pleuropneumoniae, which is composed of $\mathrm{V}$ factor-dependent and $\mathrm{V}$ factor-independent biotypes, has been transferred to the genus Actinobacillus as $A$. pleuropneumoniae (20). Similarly, Haemophilus avium, which is $\mathrm{V}$ factor dependent, has been transferred to the genus Pasteurella (18). In addition, it has been suggested that $H$. parasuis does not belong to any of the three genera now placed in the family Pasteurellaceae $(1,4)$ because of low DNA-DNA hybridization values. Furthermore, on the basis of 16S rDNA sequence analysis data, $V$ factordependent species have been shown to be distributed throughout the family $(6,7)$. These rearrangements and the remaining questions concerning the taxonomic affiliations of existing species reflect the problems in defining natural genera in the family Pasteurellaceae. Although new genera may be warranted to accommodate species such as $H$. parasuis, Actinobacillus actinomycetemcomitans, Haemophilus aphrophilus, Haemophilus segnis, and others, the natural boundaries for such genera are not easily defined. Without such a basis reorganization may cause unnecessary confusion and frustration in clinical micro- 


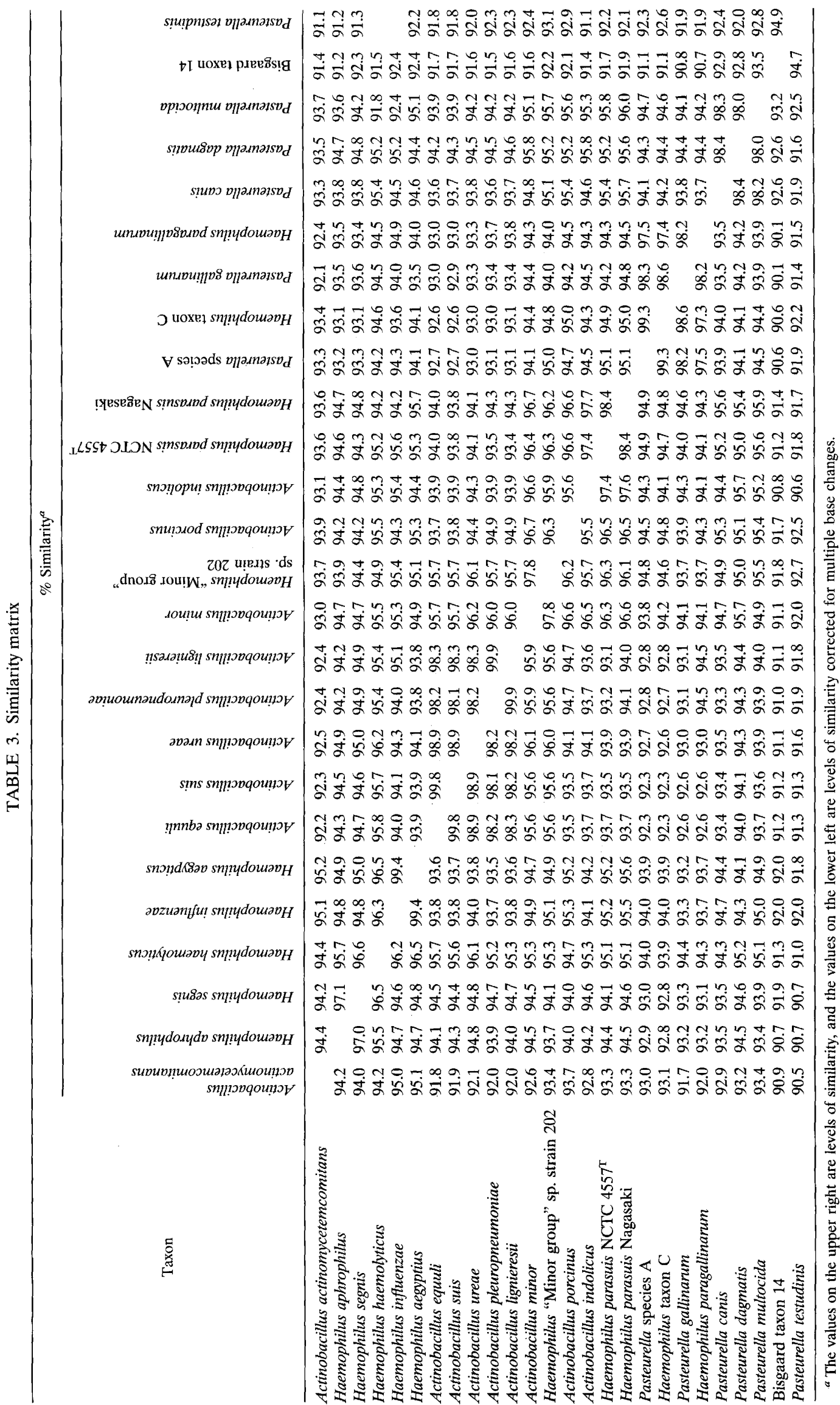




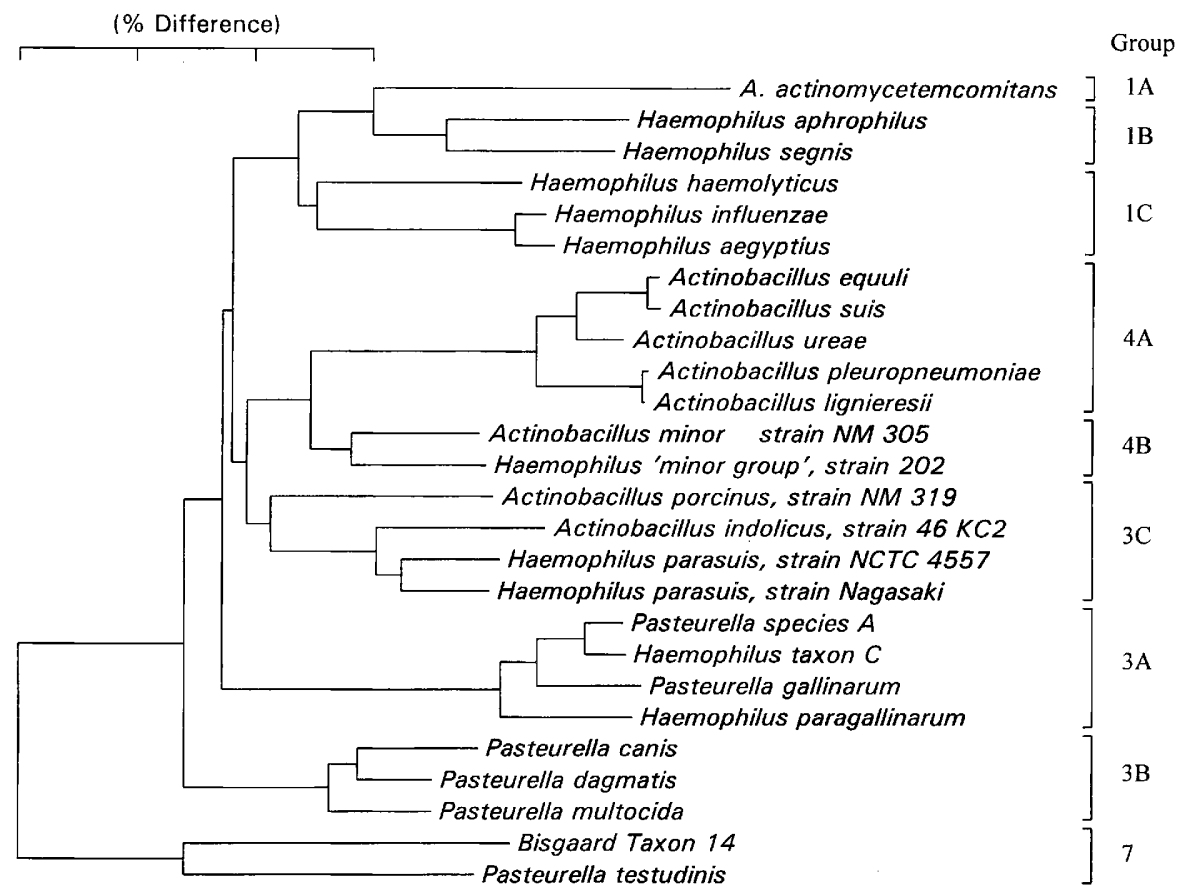

FIG. 1. Dendrogram showing the phylogenetic relationships derived from levels of $16 \mathrm{~S}$ rRNA sequence similarity for porcine species belonging to the family Pasteurellaceae and representatives of each of the seven clusters described previously (6). Bar $=3 \%$ difference in nucleotide sequence.

biology. As we doubt that new developments in technology will solve this problem, which is basically a reflection of the population structure of the family Pasteurellaceae, we chose to describe the taxa examined in this study as three new species of the genus Actinobacillus. The genus allocation is based on the 16S rDNA sequence data (Table 3 and Fig. 1), which show that the three new species are more closely related to the type species of the genus Actinobacillus than to the type species of the two other genera in the family. This is a pragmatic solution based on the considerations discussed above. Because of the limited number of taxon $C$ strains (four strains), we will not formally name this species until more strains are isolated and characterized.

Description of Actinobacillus minor sp. nov. Actinobacillus minor (mi'nor. L. comp. adj. minor, less, smaller, referring to the name of this taxon used previously [15]). Cells are gramnegative small rods (length, 1.6 to $2.4 \mu \mathrm{m}$ ). They are $\mathrm{V}$ factor dependent, $\mathrm{X}$ factor independent, nonmotile, nonhemolytic, urease positive, and indole negative. Lysine and ornithine are not decarboxylated. Ferments glucose, mannose, maltose, sucrose, and raffinose. Does not ferment arabinose, inulin, esculin, mannitol, sorbitol, and inositol. Colonies on chocolate agar

TABLE 4. Differential characteristics of porcine V factor-dependent members of the Pasteurellaceae species $^{a}$

\begin{tabular}{|c|c|c|c|c|c|c|}
\hline Characteristic & $\begin{array}{l}\text { A. minor } \\
(n=23)\end{array}$ & $\begin{array}{c}\text { A. porcinus } \\
(n=32)\end{array}$ & $\begin{array}{l}\text { A. indolicus } \\
(n=28)\end{array}$ & $\begin{array}{l}\text { A. pleuropneumoniae } \\
\qquad(n=17)\end{array}$ & $\begin{array}{l}\text { H. parasuis } \\
(n=28)\end{array}$ & $\begin{array}{l}\text { Taxon C } \\
(n=4)\end{array}$ \\
\hline $\mathrm{V}$ factor requirement & $+(+)^{b}$ & $\mathrm{~d}(+)^{c}$ & $+(+)$ & $+(+)$ & $+(+)$ & + \\
\hline Hemolysis & $-(-)$ & $-(-)$ & $-(-)$ & $\mathrm{d}(+)$ & $-(-)$ & - \\
\hline CAMP & $-(-)$ & $-(-)$ & $-(-)$ & $+(+)$ & $-(-)$ & - \\
\hline Urease & $+(+)$ & $-(-)$ & $-(-)$ & $+(+)$ & $-(-)$ & - \\
\hline Indole & $-(-)$ & $-(-)$ & $+(+)$ & $-(-)$ & $-(-)$ & - \\
\hline Catalase & $-(-)$ & $-(-)$ & $+(+)$ & $\mathrm{d}(-)$ & $+(+)$ & + \\
\hline $\mathrm{ONPG}^{d}$ & $+(+)$ & $+(+)$ & $+(+)$ & $+(+)$ & $+(+)$ & - \\
\hline$\alpha$-Fucosidase & $-(-)$ & $d(+)$ & $\mathrm{d}(+)$ & $-(-)$ & $+(+)$ & - \\
\hline \multicolumn{7}{|l|}{ Fermentation of: } \\
\hline Arabinose & $-(-)$ & $\mathrm{d}(-)$ & $-(-)$ & $-(-)$ & $-(-)$ & + \\
\hline Raffinose & $+(+)$ & $\mathrm{d}(+)$ & $+(+)$ & $-(-)$ & $-(-)$ & + \\
\hline Lactose & $+(+)$ & $\mathrm{d}(+)$ & $\mathrm{d}(-)$ & $-(-)$ & $-(-)$ & - \\
\hline Mannitol & $-(-)$ & $\mathrm{d}(+)$ & $-(-)$ & $+(+)$ & $-(-)$ & - \\
\hline
\end{tabular}

${ }^{a}$ Data from reference 15 .

$b+90 \%$ or more of the strains are positive; $-90 \%$ or more of the strains are negative; $\mathrm{d}, 11$ to $89 \%$ of the strains are positive. The reactions in parentheses are the reactions of the type strains (A. minor NM305, $A$. porcinus NM319, A. indolicus 46KC2, A. pleuropneumoniae Shope 4074, and $H$. parasuis NCTC 4557 .

${ }^{c}$ Four of the $A$. porcinus strains did not grow on agar plates, and thus $\mathrm{V}$ factor dependence was not determined. All of the remaining $A$. porcinus strains are $\mathrm{V}$ factor dependent.

${ }^{d}$ ONPG, $o$ nitrophenyl- $\beta$-D-galactopyranoside. 
are smooth, greyish, and approximately $0.8 \mathrm{~mm}$ in diameter after $48 \mathrm{~h}$ of incubation. Biochemical characteristics important for identification are shown in Table 4 . Belongs to the resident microflora of the porcine upper respiratory tract. The $\mathrm{G}+\mathrm{C}$ content of the DNA is $38.2 \mathrm{~mol} \%$. The type strain is strain NM305.

Description of Actinobacillus porcinus sp. nov. Actinobacillus porcinus (por.cin' us. M. L. adj. porcinus, pertaining to pigs, hogs). Cells are gram-negative small rods (length, 0.2 to 2.4 $\mu \mathrm{m})$. They are $\mathrm{V}$ factor dependent, $\mathrm{X}$ factor independent, nonmotile, nonhemolytic, and urease, catalase, and indole negative. Lysine and ornithine are not decarboxylated. Fermentation of most carbohydrates is variable. Does not ferment inulin, esculin, and salicin. Colonies on chocolate agar are smooth and translucent to greyish. While some isolates grow poorly on chocolate agar and their colonies are only $0.2 \mathrm{~mm}$ in diameter, others grow readily on chocolate agar and form colonies that are approximately $0.6 \mathrm{~mm}$ in diameter after $48 \mathrm{~h}$ of incubation. Biochemical characteristics important for identification are shown in Table 4. Belongs to the resident microflora of the porcine upper respiratory tract. The $\mathrm{G}+\mathrm{C}$ content of the DNA is $41.4 \mathrm{~mol} \%$. The type strain is strain NM319.

Description of Actinobacillus indolicus sp. nov. Actinobacillus indolicus (in.dol'i.cus. M.L. adj. indolicus, pertaining to indole, which is formed by the organism). Cells are gram-negative small rods (length, 0.8 to $2.4 \mu \mathrm{m}$ ). They are $V$ factor dependent, X factor independent, nonmotile, nonhemolytic, urease negative, and catalase and indole positive. Lysine and ornithine are not decarboxylated. Ferments galactose, glucose, mannose, maltose, and sucrose. Does not ferment arabinose, inulin, esculin, salicin, mannitol, sorbitol, and inositol. Colonies are greyish and opaque on chocolate agar and are $2 \mathrm{~mm}$ in diameter after $48 \mathrm{~h}$ of incubation. Cultures have a characteristic pungent smell. Biochemical characteristics important for identification are shown in Table 4. Belongs to the resident microflora of the porcine upper respiratory tract. The $\mathrm{G}+\mathrm{C}$ content of the DNA is $35.5 \mathrm{~mol} \%$. The type strain is strain $46 \mathrm{KC} 2$.

\section{ACKNOWLEDGMENTS}

K.M. thanks F. Grimont for hospitality at the Unité des Éntérobactéries.

This study was supported by a grant to K.M. from the Danish Veterinary Laboratory, the Danish Slaughterhouses, and the Danish Research Academy. Support for this research was also provided by grants 1 RO1 DE08303 and 1 RO1 DE10374 from the National Institute of Dental Research to B.J.P. and F.E.D.

\section{REFERENCES}

1. Borr, J. D., D. A. J. Ryan, and J. I. MacInnes. 1991. Analysis of Actinobacillus pleuropneumoniae and related organisms by DNA-DNA hybridization and restriction endonuclease fingerprinting. Int. J. Syst. Bacteriol. 41:121 129.

2. Brenner, D. J. 1978. Characterization and clinical identification of Enterobacteriaceae by DNA hybridization. Prog. Clin. Pathol. 7:71-117.

3. Brenner, D. J., A. C. McWhorter, J. K. Leete-Knudson, and A. G. Steiger- walt. 1982. Escherichia vulneris: a new species of Enterobacteriaceae associated with human wounds. J. Clin. Microbiol. 15:1133-1140.

4. Burbach, S. 1987. Reklassifizierung der Gattung Haemophilus Winslow et al. 1917 auf Grund der DNA-Basensequenzhomologie. Inaugural dissertation. Philipps-Universität, Marburg, Germany.

5. Christensen, J., J. E. Olesen, and M. Bisgaard. 1993. Ribotypes of Salmonella enterica serovar gallinarum biovars gallinarum and pullorum. Avian Pathol. 22:725-738.

6. Dewhirst, F. E., B. J. Paster, I. Olsen, and G. J. Fraser. 1992. Phylogeny of 54 representative strains of species in the family Pasteurellaceae as determined by comparison of 16S rRNA sequences. J. Bacteriol. 174:2002-2013.

7. Dewhirst, F. E., B. J. Paster, I. Olsen, and G. J. Fraser. 1993. Phylogeny of the Pasteurellaceae as determined by comparison of $16 \mathrm{~S}$ ribosomal ribonucleic acid sequences. Int. J. Med. Microbiol. 279:35-44.

8. Gehrke, C. W., R. A. McCune, M. A. Gama-Sosa, M. Ehrlich, and K. C. Kuo. 1984. Quantitative reverse phase high-performance liquid chromatography of major and modified nucleosides in DNA. J. Chromatogr. 301:199-219.

9. Grimont, P. A. D. 1988. Use of DNA reassociation in bacterial classification. Can. J. Microbiol. 34:541-546.

10. Handt, L. K., J. G. Fox, F. E. Dewhirst, G. J. Fraser, B. J. Paster, L. L. Yan, H. Rozmiarek, R. Rufo, and I. H. Stalis. 1994. Helicobacter pylori isolated from the domestic cat: public health implications. Infect. Immun. 62:23672374.

11. Jukes, T. H., and C. R. Cantor. 1969. Evolution of protein molecules, p. 21-132. In H. N. Munro (ed.), Mammalian protein metabolism, vol. 3. Academic Press, Inc., New York.

12. Kilian, M. 1976. A taxonomic study of the genus Haemophilus, with the proposal of a new species. J. Gen. Microbiol. 93:9-62.

13. Kilian, M., J. Nicolet, and E. L. Biberstein. 1978. Biochemical and serological characterization of Haemophilus pleuropneumoniae (Matthews and Pattison 1961) Shope 1964 and proposal of a neotype strain. Int. J. Syst. Bacteriol. 28:20-26.

14. Møller, K., L. V. Andersen, G. Christensen, and M. Kilian. 1993. Optimization of the detection of NAD dependent Pasteurellaceae from the respiratory tract of slaughterhouse pigs. Vet. Microbiol. 36:261-271.

15. Møller, K, and M. Kilian. 1990. V factor-dependent members of the family Pasteurellaceae in the porcine upper respiratory tract. J. Clin. Microbiol. 28:2711-2716.

16. Morozumi, T., U. T. Pauli, R. Braun, and J. Nicolet. 1986. Deoxyribonucleic acid relatedness among strains of Haemophilus parasuis and other Haemophilus spp. of swine origin. Int. J. Syst. Bacteriol. 36:17-19.

17. Mutters, R., P. Ihm, S. Pohl, W. Frederiksen, and W. Mannheim. 1985. Reclassification of the genus Pasteurella Trevisian 1887 on the basis of deoxyribonucleic acid homology, with proposals for the new species Pasteurella dagmatis, Pasteurella canis, Pasteurella stomatis, Pasteurella anatis, and Pasteurella langaa. Int. J. Syst. Bacteriol. 35:309-322.

18. Mutters, R., K. Piechulla, K. H. Hinz, and W. Mannheim. 1985. Pasteurella avium (Hinz and Kunjara 1977) comb. nov. and Pasteurella volantium sp. nov. Int. J. Syst. Bacteriol. 35:5-9.

19. Perrone, P. A., and P. R. Brown. 1984. Ion-pair-chromatography of nucleotides. J. Chromatogr. 317:301-310.

20. Pohl, S., H. U. Bertschinger, W. Frederiksen, and W. Mannheim. 1983. Transfer of Haemophilus pleuropneumoniae and the Pasteurella haemolyticalike organism causing porcine necrotic pleuropneumonia to the genus $\mathrm{Acti}$ nobacillus (Actinobacillus pleuropneumoniae comb. nov.) on the basis of phenotypic and deoxyribonucleic acid relatedness. Int. J. Syst. Bacteriol. 33:510-514.

21. Saitou, N., and M. Nei. 1987. The neighbor-joining method: a new method for reconstructing phylogenetic trees. Mol. Biol. Evol. 4:406-425.

22. Stackebrandt, E., and B. M. Goebel. 1994. Taxonomic note: a place for DNA-DNA reassociation and 16S rRNA sequence analysis in the present species definition in bacteriology. Int. J. Syst. Bacteriol. 44:846-849.

23. Wayne, L. G., D. J. Brenner, R. R. Colwell, P. A. D. Grimont, O. Kandler, M. I. Krichevsky, L. H. Moore, W. E. C. Moore, R. G. E. Murray, E. Stackebrandt, M. P. Starr, and H. G. Trüper. 1987. Report of the Ad Hoc Committee on Reconciliation of Approaches to Bacterial Systematics. Int. J. Syst. Bacteriol. 37:463-464. 